\title{
Developing intercultural awareness in language teaching: Insights from EFL lecturers in Turkey*
}

\section{APA Citation:}

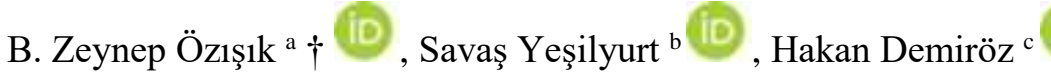

Özışık, B. Z., Yeşilyurt, S., \& Demiröz, H. (2019). Developing intercultural awareness in language teaching: Insights from EFL lecturers in Turkey. Journal of Language and Linguistic Studies, 15(4), 1436-1458.

Submission Date:09/09/2019

Acceptance Date:30/10/2019

\begin{abstract}
This study aims to reveal EFL lecturers' opinions about intercultural education and classroom practices including teaching materials, classroom activities, assessment, and teachers' role for developing intercultural awareness. To gain insights about the current situation in EFL classrooms at a university level in Turkey, lecturers' opinions and classroom practices have been examined through a questionnaire and an interview. This study, combining both quantitative and qualitative research, was designed according to the mixed method procedure and followed the sequential explanatory strategy. The study covered 172 EFL lecturers from preparatory schools of six state universities, and 12 EFL lecturers selected randomly joined the interview voluntarily. The participating institutions were Atatürk University, Cumhuriyet University, Erciyes University, Hacı Bektaş Veli University, Karabük University, and Karadeniz Technical University. The quantitative results show that although lecturers are aware of the importance of integrating both home and target culture into the classes, and developing learners' interactional skills, intercultural communicative competence and intercultural sensitivity, they are not sure about how to put intercultural learning into practice for EFL classroom tasks and activities. Accordingly, the results of the interview present the problems that prevent teaching about intercultural awareness and reveal that lecturers need guidance and training to practice confidently intercultural competence teaching in the classroom, especially in terms of assessment methods as they do not have a clear idea about the assessment and evaluation methods to apply with intercultural competence.
\end{abstract}

(C) 2019 JLLS and the Authors - Published by JLLS

Keywords: Teachers of EFL; language teaching; target culture; intercultural awareness; intercultural sensitivity

\section{Introduction}

The changes because of globalization in terms of cultural, social, and political grounds call for the functional innovations in educational systems to prepare learners to handle global issues (Wang, Lin, Spalding, Odell, \& Klecka, 2011; Stromquist \& Monkman, 2014). As it is the case that "intercultural education is needed throughout the world to prepare students for a future in a culturally diverse world"

\footnotetext{
* This study was developed from the doctoral dissertation of the corresponding author.

${ }^{\dagger}$ Corresponding author. Tel.: +0-5537678574

E-mail address: b.zeynep.ozisik@bozok.edu.tr
} 
(Ferguson-Patrick \& Jolliffe, 2018, p. 3) the most known and widely accepted models to intercultural learning in FL education have been suggested by Bennett (1993) and Byram (1997) who recognize the necessity of developing intercultural dialogue between societies.

Stressing the notion that intercultural sensitivity is a developmental process which is not inherited naturally Bennett (1993) introduces "Developmental Model of Intercultural Sensitivity" (DMIS), which "emerges from systematic observations" (Bennett, 2004, p. 9), in an attempt to "understand why people behave as they normally do in the face of cultural difference, how they are likely to change in response to education, and what the ultimate goal is toward which our efforts are expended" (p. 21).

Bennett's (1993) model including "stages of personal growth" (p. 22) explores one's cognitive and conscious self-awareness with "a linear assumption built into the model that beginning, intermediate, and end stages can be described" (p. 26). The model describes the personal changes from a developmental perspective as moving away from ethnocentrism to ethnorelativism. Bennett (1993, 2004, and 2009) explains the ethnocentrism as the concept that one assumes his/her cultural realities are superior to all other cultures. Joining the concept of ethnorelativism as the opposite of ethnocentrism, Bennett (2004, p. 1) defines it as “the experience of one's own beliefs and behaviours as just one organization of reality among many viable possibilities." The sequence of these stages leads one to gain intercultural competence. According to Bennett (2004), creating greater intercultural sensitivity which enables self-awareness and intercultural awareness increases intercultural communication - a qualification associated with intercultural competence as suggested by Byram (1997).

In the last decade of the 20th Century the pioneering works by prolific British scholar Michael Byram (1997) brought up the issue of intercultural competence to the agenda suggesting a descriptive model in an attempt to enhance the knowledge and the experience on intercultural competence (Agudelo, 2007; Aguilar, 2007; Holmes \& O’Neill, 2012; Lee, 2012; Hoff, 2014; Gu, 2016; Lin, Shie \& Holmes; 2017). According to Byram $(1989,1997,2001)$ language learning is an interactive and meaningful process. His model for Intercultural Communicative Competence (ICC) sets the framework to promote linguistic, discourse, and sociocultural competence all together. He argues that cultural learning should go beyond superficial "C"ultural facts and requires learners to eliminate prejudices about other cultures through empathic introspection and become "Intercultural speaker" (Byram, 1997, p. 31); and this kind of culture learning "possesses competences" to "assist individuals to participate in intercultural communication" (Taguchi, Li, \& Xiao, 2016, p. 775). In Figure 1, Byram (1997) describes the qualities of intercultural speakers "who are committed to turning intercultural encounters into relationships based on mutual respect and understanding" (Hoff, 2014, pp. 508-509). The framework of the model consisting of five factors, namely savoirs, is presented below:

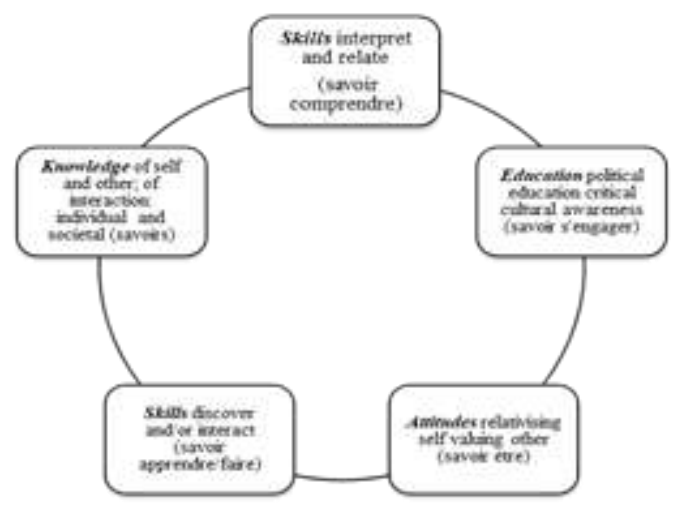

Figure 1. Byram’ factors in intercultural communication (Byram, 1997, p. 34). 
Keeping in mind the need for linking language knowledge and cultural content knowledge, language learners should develop their ICC skills by acquiring Byram's savoirs, which provide a focus for thinking curiously about other cultures, its products and social groups, and for connecting, relating, and evaluating critically one's own and other cultures by means of interaction and communication (Sellami, 2000). While the ICC model helps learners attain in-depth cultural learning it also facilitates students to become qualified users of the target language in terms of socially appropriate communication.

Pedagogical implications in language learning shift from efficiency to competencies in communication while the cultural, racial, ideological, and political issues raise the importance of mutual understanding and exchange of empathy. Hence, sociocultural perspectives assuming that "learning emerges from the social, cultural, and political spaces in which it takes place, and through the interactions and relations that occur between learners and teachers" (Nieto, 2002, p. 5) suggest integration of cultural issues and raising interactions. Consequently, L2/FL education turns its educational goals to provide learners with "intercultural sensitivity" (Bennett, 1993) by suggesting ICC (Byram, 1989, 1990, 1997; Corbett, 2003; Arasaratnam \& Doerfel, 2005; Liddicoat, 2005; Sercu, 2006).

This study presents a literature review in which material selection, classroom activities, assessment methods, and teachers' roles are provided to help EFL language lecturers develop learners' intercultural awareness. The study stresses the significant role of lecturers to extend the goals of EFL teaching from restricted points of view on teaching cultural elements to the development of intercultural awareness. Hence, this study aims to reveal EFL lecturers' opinions about intercultural education and classroom practices including teaching materials, classroom activities, assessment, and teachers' role for developing intercultural awareness.

\subsection{Literature review}

\subsubsection{Material selection}

As intercultural competence raises the issues of empathy, mutual understanding, and diversity, the realistic picture of foreign cultures should be provided in the textbooks (Byram, 1989). Byram (1989) argues that textbooks should be a means for forming an opinion about the daily routines of the foreign culture "which avoids the pitfalls of family idyll and of superficial tourism" (p.17). Clouet (2006) suggests two textbooks which are rich in materials that open the way to "compare cultures and to take a critical perspective" (p.58): English File (Oxendon \& Latham-Koneig, 2000) and Interchange (Richards, 2000). By stressing the dominant role of the textbook as a major material for the language teachers Sercu (2006) suggests textbook authors in to "design teaching materials that aim to promote the acquisition of intercultural competence amongst learners" (p.70). He emphasizes the need for developing students' "intercultural skills and attitudes" by combining language teaching and cultural knowledge (p. 70). Byram (1989) offers As Others See Us, designed by anthropologist Hurman (1977), as a textbook that provides materials to get into "anthropological insights" (p.78). Byram (1989) suggests the book as it involves concepts like stereotype and gives place to "others' reported views" (p. 78).

Although the textbooks are ranked as the major source of material, the developments in technology and easy access to Internet enable language teachers to enrich the classrooms with wide range of materials such as "primary texts", "authentic materials", "technological resources" (Clouet, 2006, p. 58), "visual aids" (Chastain, 1976; Bush, 2007), "online forums", "episodes" (Sayer \& Meadows, 2012), and "ethnographic materials" such as photographs, field notes, and recorded interviews (Duff \& Mayes, 2001).

Sayer and Meadows (2012), applying "critical language pedagogy" and "critical discourse analysis" deal with the stereotype in the language classroom for a deeper understanding of intercultural awareness. For the material the authors use three texts: an episode from a TV programme wherein "the national 
stereotypes of Mexicans" are used to make a joke, the press statement of BBC, and selections of comments posted in forums as a reaction. In order to encourage students to discuss about diversity the authors provide students "several texts that illustrate that people commonly do frame their understandings of others in terms of their putative national culture" (p. 276). By integrating cultural and media studies into language classrooms the authors aim to stress the significance of "the study of the sociocultural practices of others" (p. 277).

In their project, Duffy and Mayes (2001) provide students with "ethnographic materials" and encourage them "to learn how to conduct ethnographic data collection" (p. 93). The project focuses on goals such as developing "attitudes of curiosity and openness" towards the foreign culture, "an understanding of 'otherness", and "feeling of empathy" (p. 95). The authors deciding five topics gather video and documentary materials "obtained from tourist offices", "BBC and independent companies", "articles from the French press, statistical information", and "through the Internet and e-mail" (p. 96). The project highlights the significant role of designing ethnographic interview through which students find "the opportunity to analyse a number of different responses" (p. 97).

As we live in an era of technological advancements which make it easy to access Internet and online communication tools, the materials to be used with new media studies and cultural studies in language classrooms are highly recommended by scholars and researchers to catch up with the needs of increasingly multicultural and interrelated world.

\subsubsection{Classroom activities}

"The unavoidable realization" (Gonzalez-Lloret \& Ortega, 2014, p. 1), which brings up the fact that the developments in communication technologies and full access to Internet wirelessly, essentially, make the digital devices such as tablets, smartphones, e-books part of a daily routine of students, demands "instructional responses" (p. 1) to the "digital technology realities" (p. 1) by integrating technology into the language instruction design and classroom activities. Welcoming Web 2.0 technologies in the classroom activities the language teachers allow students to engage in social interaction and authentic environment and to gain the digital skills. Technology-mediated instructional designs "for their potential to create authentic and interactive contexts" (Canto, Graaff, \& Jauregi, 2014, p. 184) support and enhance intercultural competence of language students. As Müller-Hartmann and Ditfurth (2010, p. 20) pinpoint that "the texts which learners have access to on the Internet are culturally grounded", technology mediated tasks enable students to gain sociocultural perspectives.

Lee (2012), stressing the fact that "with the ever-increasing mobility of people throughout the world" (p.7) it is of the top priority "for foreign language learners to develop intercultural communicative competence" (p.7), employs a study with 16 American students learning Spanish in Spain. The study aiming to "develop learners' intercultural knowledge and awareness through reflective blogs and foster cross-cultural communication through ethnographic interviews with native informants" (p.10) shows the use of Web 2.0 tools and ethnographic research such as interviews in FL classrooms are highly effective in promoting interaction and developing intercultural insights.

Using questionnaires and interviews Liu and Fang (2017) "investigate how English language learners' perceptions and awareness of home culture influence the social practice of intercultural communication" (p.25). The researchers conducting the study in southeast China at a university engage students in comparison and critical thinking activities. The study asserting the dominance of western cultures in terms of the target culture in ELT courses suggests the integration of home culture to challenge "the sole benchmark" of western cultures "for the transmission of values and cultures" (p. 34). In line with the anthropological point of Byram (1989) the study stresses the importance and influence of classroom activities involving both home and target culture discussions. 
Ganem-Gutiérrez (2014) framing the tasks from sociolinguistic perspective supported by technology-mediated tasks proposes "3D virtual world environments" (p. 213). The author describes three-dimensional virtual worlds (3D VWs) as "in-world residents (i.e. users, participants) use avatars, that is, graphic or visual representations of the user, to create their own personas, identities, and characters in order to engage in interaction with other avatars" (p. 214). The author highlights the main aims of this kind of game-like application as the development of "strong sense of social presence" (p. 216), contributing to "decreased levels of anxiety" (p. 218), promoting "identity exploration" (p. 220) and achieving "self-constructed goals" of the students (p. 225).

\subsubsection{Assessment and evaluation}

On selecting a method of assessment, researchers and teachers should consider that it must suit the purpose of teaching tasks. "Quantitative scales of intercultural competence" (Perry \& Southwell, 2011, p. 460) measure learners' "intercultural sensitivity” (Bennett, 1993), behaviour (Koester \& Olebe, 1988, cited in Koester \& Lustig, 2015), cross-cultural adaptability (Kelley \& Meyers, 1995, cited in Perry \& Southwell, 2011) and cross cultural sensitivity (Cushner, 1992, cited in Mahon \& Cushner, 2014). Based on Bennett's (1993) Developmental Model of Intercultural Sensitivity (DMIS), which "was created from the direct observations in the qualitative tradition" (Garrett-Rucks, 2014, p. 183), the intercultural development inventory (IDI) (Hammer, Bennett, \& Wiseman, 2003), consisting 50 items with five-point Likert scales, measures intercultural sensitivity by assessing six dimensions of DMIS -denial, defence reversal, minimisation, acceptance, adaptation, integration- (Hammer, Bennett, \&Wisemann, 2003).

The scales for quantitative measure of intercultural competence are mainly based on self-reporting surveys or questionnaires. To get more satisfactory and authentic assessment researchers, teachers, and trainers should apply also qualitative assessment methods. Qualitative assessment methods which offer process-oriented and student-centred evaluations from the constructivist paradigm of sociocultural theory include written reports, portfolios, interviews by which students are driven to think deeply and make analysis on the process of their cognitive development (Gipps, 2002).

By combining both quantitative and qualitative measures Angelica Galante (2014) carries a five-step project of 6 weeks with students of English as an Additional Language (EAL) studying in a multicultural classroom. The researcher using Bennett's DMIS model explores students' developmental process describing how the students move away from ethnocentric stages to ethnorelativism (Galante, 2014). In this five-step project, the researcher allows the students to engage in their own assessment process by involving students in "reflective discussions, script writing, video recording scenes, editing, and final reflection" (p. 53).

It is suggested that combining both quantitative and qualitative measures is the best way to integrate students into the assessment period through which they can evaluate self-awareness and be driven to critical self-discovery. However, teachers' awareness and training on the assessment tools of intercultural teaching and learning play a major role for the educational goals.

\subsubsection{Teachers' roles}

Living in the era of communication as a result of high speed of technological developments and widespread use of Internet, FL teachers are required "to change their conception of their own role from that of a transmitter of knowledge to that of a multi-role educator" (Littlewood, 2014, p. 352). By designing lessons in the intent of "developing students' tolerance of a cultural phenomenon in the target culture which is alien to them" (Madjarova, Botsmanova, \& Stamatova, 2001, p. 236) teachers help students "accept the validity of the target culture" (Madjarova, Botsmanova, \& Stamatova, 2001, p. 244) rather than imposing students to accept a particular thought or view of a foreign culture as Parsons and Junge (2001, p. 205) point the changing roles for teachers "the teacher exchanges the traditional role of someone who imparts knowledge for the role of consultant and counsellor". 
Setting her argument in awareness rising and intercultural sensitivity, Porto (2010) suggests teachers to make "classrooms culturally sensitive places to learn" (p. 47). Also, in their ethnographic research projects Morgan (2001) and Georgieva (2001) position teachers in the role of "ethnographer and facilitator" (Morgan, 2001, p. 21) and encourage teachers "to make the crucial step from theory to practice" (Georgieva, 2001, pp. 77-78).

Rather than teaching just high culture of literature, teachers should make students be aware of "the views of a people, its variety and its essence" (Harrison, 1990, p. 1). When intercultural education is integrated into teacher training programmes or ELT courses to make the preservice teachers aware of methodology in terms of assessment, activities, and their educational role teachers will be prepared to deal with problems.

\subsection{Research questions}

The authors prepared the study in order to address the following research questions:

1) To what extend do EFL lecturers at preparation schools of universities in Turkey integrate intercultural education into EFL classrooms in terms of selecting materials, classroom tasks and activities, assessment, and teachers' role?

2) How do EFL lecturers perceive intercultural education in terms of Byram's intercultural communicative competence (ICC) model, Bennet's model of intercultural sensitivity, and Vygotsky's interactional theory?

\section{Method}

\subsection{Participants}

The questionnaire was conducted to 172 lecturers of EFL who were teaching at preparation schools in 6 state universities in Turkey. Participating universities were Cumhuriyet University, Atatürk University, Erciyes University, Hacı Bektaş Veli University, Karabük University, and Karadeniz Technical University. And among the participants taking part in the quantitative research, 91 were female while the number of the male participants was 81.12 of the participants were selected randomly in terms of paying attention to gender equality for the qualitative research. However, 5 male and 7 female lecturers voluntarily accepted to join the qualitative research.

\subsection{Instruments}

This study, combining both quantitative and qualitative methods, was designed according to the mixed method procedure, which enabled the researcher to gain a wide scope about the topic investigating both numbers and words through which a deep understanding of participants' insights was expected to be received (Sandelowski, 2000; Creswell, 2012, 2014; Almalki, 2016;). By mixing both quantitative and qualitative approach in a single study the researcher aims to analyse and "confirm findings from different data sources" (Creswell, 2014, p. 24) rather "than either method by itself" (Creswell, 2012, p. 535).

The researcher used a modified survey instrument after obtaining the required permission from the developer of the questionnaire. The questionnaire was composed of two sections. Section A provided the demographic data such as age, gender, working experience, educational background, name of institutions, and a yes/no question about intercultural awareness. Section B focusing on the main purpose of the study involved 7 questions including sub statements arranged according to 5-point Likert Scale 
format. In order to obtain the qualitative data, the researcher conducted a semi-structured interview. The researcher prepared interview questions both in Turkish and in English. Only one of the interviewees out of 12 preferred English language. The interviews lasted nearly half an hour during which the researcher paid attention to be respectful and sensitive to the interviewees approaching them friendly and in an ethical way.

\subsection{Data analysis}

As "a multivariate statistical procedure" (Williams, Onsman, \& Brown, 2010, p. 2) factor analysis method was used to analyse the data. Factor analysis provides the researcher with understanding and interpreting the relationships easily by summarising the data under groups or factors (Yong \& Pearce, 2013). In this study the items of the questionnaire are collected under five factors as listed below:

- Home and target culture in EFL classrooms

- Classroom tasks and activities

- Vygotskian theory of interaction

- Byram's ICC model

- Bennett's model of intercultural sensitivity

Descriptive statistics for the means of each factor in terms of the lecturers' awareness and perceptions are presented at first hand, and then the means by the demographic factors are shown in detail by providing variables.

Bearing in mind the significant attribution of the qualitative research which provides insights and perspectives of the participants, the researcher conducted a semi-structured interview. By relating the interview to the current study, the researcher outlines the interview questions in two main concepts: culture and intercultural education. First half of the questions (Q1-2-3-4) were prepared in an attempt to highlight lecturers' perception of culture. The second part (Q5-6-7-8-9-10-11-12) puts more focus on lecturers' understanding of intercultural competence and awareness, and classroom practices. The interviews took almost half an hour and were recorded in the office of the participants, as it was important to allow the participants to feel comfortable. The researcher enumerates the informants as SP1, SP2, SP3, etc. in order to hold the personal information of each participant confidential as it should be according to the ethical issues.

\subsection{Reliability and validity}

As it was essential to measure the reliability of the data instrument, Cronbach's Alpha reliability test was conducted for each factor of the questionnaire in order to present the reliability value of the factors. Table 1 provides the results of the test for each factor.

Table 1. Cronbach's Alpha reliability test results for each factor

\begin{tabular}{lll}
\hline Factors & Items (Questions) & $\begin{array}{l}\text { Cronbach's } \\
\text { Internal } \\
\text { Consistency }\end{array}$ \\
\hline $\begin{array}{l}\text { Home and Target Culture in } \\
\text { EFL Classrooms }\end{array}$ & $1,2,3,11,16,19$ & $\mathbf{. 7 6 4}$ \\
$\begin{array}{l}\text { Classroom Tasks and Activities } \\
\text { Vygotskian Theory of }\end{array}$ & $6,7,14,21,22,23,24,25,26,32,33$ & $\mathbf{. 8 1 4}$ \\
$\begin{array}{l}\text { Interaction } \\
\text { Byram's ICC Model }\end{array}$ & $5,10,12,13,15,28$ & $\mathbf{. 8 6 6}$ \\
$\begin{array}{l}\text { Bennett's Model of } \\
\text { Intercultural Sensitivity }\end{array}$ & $4,8,9,17,18,29,30,31$ & $\mathbf{. 7 4 1}$ \\
Total & 33 & $\mathbf{. 7 5 0}$ \\
\hline
\end{tabular}


Overall reliability coefficient was also calculated as 0.824 , suggesting that all items were reliable according to the alpha consistency. Considering the reliability value of the instrument measured as .824 , we can state that the factors have a good level of reliability value according to the Cronbach's Alpha internal consistency levels.

\section{Results}

\subsection{Quantitative results}

The questionnaire used as a means for collecting the quantitative data of the study includes thirty three questions under five factors aiming to find out the participants' perceptions of using home and target culture in EFL classrooms and classroom tasks and activities in terms of intercultural perspectives, awareness of Vygotsky's theory of interaction, Byram's intercultural communicative competence (ICC), and Bennett's model of intercultural sensitivity.

Table 2. Descriptive statistics of the factors

\begin{tabular}{lccccc}
\hline Factors & $\mathrm{N}$ & Minimum & Maximum & Mean & Std. Deviation \\
\hline Home and Target Culture in EFL & 172 & 1.00 & 5.00 & 3.4810 & .67494 \\
Classrooms & & & & & \\
Classroom Tasks and Activities & 172 & 1.00 & 4.78 & 3.2533 & .54671 \\
Vygotskian Theory of Interaction & 172 & 1.00 & 11.50 & 3.2820 & .88092 \\
Byram's ICC Model & 172 & 1.00 & 5,17 & 3,2862 & .69341 \\
Bennett's Model of Intercultural & 172 & 1.00 & 5.00 & 3.4873 & .69129 \\
Sensitivity & & & & & \\
Valid N (listwise) & 172 & & & & \\
\hline
\end{tabular}

Considering the means of the factors as shown in Table 2 it is seen that the levels of awareness are 3.4810 (70\%) in Home and Target Culture in EFL Classrooms, 3.2533 (65\%) in Classroom Tasks and Activities, 3.2820 (66\%) in Vygotskian Theory of Interaction, 3.2862 (66\%) in Byram's ICC Model, and $3.4873(70 \%)$ in Bennett's Model of Intercultural Sensitivity. In general, looking at the results of mean we can note that the lecturers' intercultural awareness in terms of the factors is over $50 \%$ and there are not significant differences among the factors.

In order to investigate the findings in detail, variables of demographic data for each factor such as age, gender, working experience, name of institution, educational background, and issues of intercultural awareness are presented.

Table 3. Means of the factors for age groups

\begin{tabular}{lllllll}
\hline Age & & $\begin{array}{l}\text { Home and } \\
\text { Target } \\
\text { Culture in } \\
\text { EFL } \\
\text { Classrooms }\end{array}$ & $\begin{array}{l}\text { Classroom } \\
\text { Tasks and } \\
\text { Activities }\end{array}$ & $\begin{array}{l}\text { Vygotskian } \\
\text { Theory of } \\
\text { Interaction }\end{array}$ & $\begin{array}{l}\text { Byram's ICC } \\
\text { Model }\end{array}$ & $\begin{array}{l}\text { Bennett's } \\
\text { Model of } \\
\text { Intercultural } \\
\text { Sensitivity }\end{array}$ \\
& & & & & \\
\hline $\mathbf{2 3 - 3 0}$ & Mean & 3.6159 & 3.4025 & 3.3283 & 3.4476 & $\mathbf{3 . 6 6 8 4}$ \\
& N & 82 & 82 & 82 & 82 & 82 \\
& Std. & .64772 & .48853 & .59235 & .65126 & .60312 \\
& Deviation & & & & & \\
\hline $\mathbf{3 1 - 4 0}$ & Mean & 3.3825 & 3.0908 & 3.3390 & 3.1588 & $\mathbf{3 . 4 1 8 5}$ \\
& N & 59 & 59 & 59 & 59 & 59 \\
\hline
\end{tabular}




\begin{tabular}{lllllll}
\hline & Std. & .69454 & .57141 & 1.24893 & .73384 & .74320 \\
& Deviation & & & & & \\
\hline $\mathbf{4 1 - 5 0}$ & Mean & $\mathbf{3 . 3 8 8 9}$ & 3.2296 & 3.1151 & 3.1381 & 3.3051 \\
& $\mathrm{~N}$ & 21 & 21 & 21 & 21 & .41 \\
& Std. & .48113 & .37306 & .52538 & .49691 & .50783 \\
& Deviation & & & & & \\
\hline $\mathbf{5 1 +}$ & Mean & $\mathbf{3 . 1 5 0 0}$ & 3.0378 & 2.9167 & 3.0267 & 2.7900 \\
& $\mathrm{~N}$ & 10 & 10 & 10 & 10 & .85189 \\
& Std. & .94101 & .82983 & .81650 & .91068 & \\
& Deviation & & & & 3.2862 & $\mathbf{3 . 4 8 7 3}$ \\
Total & Mean & 3.4810 & 3.2533 & 3.2820 & 172 & .69129 \\
& N & 172 & 172 & 172 & .69341 & \\
& Std. & .67494 & .54671 & .88092 & & \\
& Deviation & & & & & \\
\hline
\end{tabular}

Table 3 demonstrates that while young lecturers' awareness of Bennett's model of intercultural sensitivity is higher, older lecturers are more aware of significant role of using home and the target culture in the EFL classroom.

Table 4. Means of the factors for gender groups

\begin{tabular}{|c|c|c|c|c|c|c|}
\hline Gender & & $\begin{array}{l}\text { Home and } \\
\text { Target } \\
\text { Culture in } \\
\text { EFL } \\
\text { Classrooms }\end{array}$ & $\begin{array}{l}\text { Classroom } \\
\text { Tasks and } \\
\text { Activities }\end{array}$ & $\begin{array}{l}\text { Vygotskian } \\
\text { Theory of } \\
\text { Interaction }\end{array}$ & $\begin{array}{l}\text { Byram's } \\
\text { ICC Model }\end{array}$ & $\begin{array}{l}\text { Bennett's } \\
\text { Model of } \\
\text { Intercultural } \\
\text { Sensitivity }\end{array}$ \\
\hline Male & $\begin{array}{l}\text { Mean } \\
\mathrm{N} \\
\text { Std. } \\
\text { Deviation }\end{array}$ & $\begin{array}{l}\mathbf{3 . 4 3 0 0} \\
81 \\
.65557\end{array}$ & $\begin{array}{l}3.2444 \\
81 \\
.59367\end{array}$ & $\begin{array}{l}3.3591 \\
81 \\
1.10000\end{array}$ & $\begin{array}{l}3.2848 \\
81 \\
.70392\end{array}$ & $\begin{array}{l}3.4295 \\
81 \\
.69583\end{array}$ \\
\hline Female & $\begin{array}{l}\text { Mean } \\
\text { N } \\
\text { Std. } \\
\text { Deviation }\end{array}$ & $\begin{array}{l}3.5264 \\
91 \\
.69217\end{array}$ & $\begin{array}{l}3.2612 \\
91 \\
.50445\end{array}$ & $\begin{array}{l}3.2134 \\
91 \\
.62351\end{array}$ & $\begin{array}{l}3.2875 \\
91 \\
.68782\end{array}$ & $\begin{array}{l}\mathbf{3 . 5 3 8 7} \\
91 \\
.68696\end{array}$ \\
\hline Total & $\begin{array}{l}\text { Mean } \\
\mathrm{N} \\
\text { Std. } \\
\text { Deviation }\end{array}$ & $\begin{array}{l}3.4810 \\
172 \\
.67494\end{array}$ & $\begin{array}{l}3.2533 \\
172 \\
.54671\end{array}$ & $\begin{array}{l}3.2820 \\
172 \\
.88092\end{array}$ & $\begin{array}{l}3.2862 \\
172 \\
.69341\end{array}$ & $\begin{array}{l}\mathbf{3 . 4 8 7 3} \\
172 \\
.69129\end{array}$ \\
\hline
\end{tabular}

Statistics for gender variable for the factors in Table 4 reveals that the highest means are $3.43(69 \%)$ for male and $3.53(71 \%)$ for female participants. It is shown in the table that male lecturers are more aware of the importance of home and target culture in the EFL classroom. On the other hand, female lecturers' awareness is higher for Bennett's model of intercultural sensitivity. 
Table 5. Means of the factors for groups of experience

\begin{tabular}{|c|c|c|c|c|c|c|}
\hline Experience & & $\begin{array}{l}\text { Home and } \\
\text { Target } \\
\text { Culture in } \\
\text { EFL } \\
\text { Classrooms } \\
\end{array}$ & $\begin{array}{l}\text { Classroom } \\
\text { Tasks and } \\
\text { Activities }\end{array}$ & $\begin{array}{l}\text { Vygotskian } \\
\text { Theory of } \\
\text { Interaction }\end{array}$ & $\begin{array}{l}\text { Byram's } \\
\text { ICC Model }\end{array}$ & $\begin{array}{l}\text { Bennett's } \\
\text { Model of } \\
\text { Intercultural } \\
\text { Sensitivity }\end{array}$ \\
\hline 0-1 years & $\begin{array}{l}\text { Mean } \\
\mathrm{N} \\
\text { Std. } \\
\text { Deviation }\end{array}$ & $\begin{array}{l}3.7667 \\
5 \\
.49441\end{array}$ & $\begin{array}{l}3.5778 \\
5 \\
.30832\end{array}$ & $\begin{array}{l}3.2500 \\
5 \\
.25000\end{array}$ & $\begin{array}{l}3.4333 \\
5 \\
.34561\end{array}$ & $\begin{array}{l}\mathbf{4 . 0 0 0 0} \\
5 \\
.76547\end{array}$ \\
\hline 2-5 years & $\begin{array}{l}\text { Mean } \\
\mathrm{N} \\
\text { Std. } \\
\text { Deviation }\end{array}$ & $\begin{array}{l}3.6280 \\
56 \\
.60885\end{array}$ & $\begin{array}{l}3.3579 \\
56 \\
.49668\end{array}$ & $\begin{array}{l}3.4003 \\
56 \\
.59020\end{array}$ & $\begin{array}{l}3.4298 \\
56 \\
.68206\end{array}$ & $\begin{array}{l}\mathbf{3 . 7 0 2 2} \\
56 \\
.54829\end{array}$ \\
\hline $\begin{array}{l}6-10 \\
\text { years }\end{array}$ & $\begin{array}{l}\text { Mean } \\
\mathrm{N} \\
\text { Std. } \\
\text { Deviation } \\
\end{array}$ & $\begin{array}{l}3.4796 \\
49 \\
.71979\end{array}$ & $\begin{array}{l}3.2399 \\
49 \\
.62536\end{array}$ & $\begin{array}{l}3.4286 \\
49 \\
1.30104\end{array}$ & $\begin{array}{l}3.3150 \\
49 \\
.68756\end{array}$ & $\begin{array}{l}\mathbf{3 . 5 4 5 2} \\
49 \\
.72412\end{array}$ \\
\hline $11+$ years & $\begin{array}{l}\text { Mean } \\
\mathrm{N} \\
\text { Std. } \\
\text { Deviation }\end{array}$ & $\begin{array}{l}\mathbf{3 . 3 2 6 3} \\
62 \\
.68428\end{array}$ & $\begin{array}{l}3.1432 \\
62 \\
.51993\end{array}$ & $\begin{array}{l}3.0618 \\
62 \\
.66768\end{array}$ & $\begin{array}{l}3.1220 \\
62 \\
.70700\end{array}$ & $\begin{array}{l}3.2059 \\
62 \\
.68589\end{array}$ \\
\hline Total & $\begin{array}{l}\text { Mean } \\
\mathrm{N} \\
\text { Std. } \\
\text { Deviation }\end{array}$ & $\begin{array}{l}3.4810 \\
172 \\
.67494\end{array}$ & $\begin{array}{l}3.2533 \\
172 \\
.54671\end{array}$ & $\begin{array}{l}3.2820 \\
172 \\
.88092\end{array}$ & $\begin{array}{l}3.2862 \\
172 \\
.69341\end{array}$ & $\begin{array}{l}\mathbf{3 . 4 8 7 3} \\
172 \\
.69129\end{array}$ \\
\hline
\end{tabular}

Considering the experience of the lecturers we can state that all the groups of experience except for group 11+ show highest awareness for Bennett's model of intercultural sensitivity. Lecturers with working experience over 11 years are more aware of using home and the target culture in the EFL classroom. Table 5 suggests that lecturers' awareness of Bennett's model is getting higher while working experience is decreasing.

Table 6. Means of the factors for groups of institutions

\begin{tabular}{lllllll}
\hline Institution & & $\begin{array}{l}\text { Home and } \\
\text { Target } \\
\text { Culture in } \\
\text { EFL } \\
\text { Classrooms }\end{array}$ & $\begin{array}{l}\text { Classroom } \\
\text { Tasks and } \\
\text { Activities }\end{array}$ & $\begin{array}{l}\text { Vygotskian } \\
\text { Theory of } \\
\text { Interaction }\end{array}$ & $\begin{array}{l}\text { Byram's } \\
\text { ICC Model }\end{array}$ & $\begin{array}{l}\text { Bennett's } \\
\text { Model of } \\
\text { Intercultural } \\
\text { Sensitivity }\end{array}$ \\
\hline Cumhuriyet & Mean & 3.3333 & 3.0417 & 3.1875 & 3.1250 & $\mathbf{3 . 4 5 3 1}$ \\
Uni. & $\mathrm{N}$ & 8 & 8 & 8 & 8 & 8 \\
& Std. & .83571 & .40690 & .84251 & 1.02644 & .74083 \\
& Deviation & & & & & \\
\hline Atatürk Uni. & Mean & 3.5083 & 3.2492 & 3.2125 & 3.3250 & $\mathbf{3 . 7 1 0 0}$ \\
& $\mathrm{N}$ & 20 & 20 & 20 & 20 & 20 \\
& Std. & .53660 & .61002 & .50181 & .50862 & .65827 \\
& Deviation & & & & & 3.3199 \\
\hline Erciyes Uni. & Mean & $\mathbf{3 . 3 9 6 5}$ & 3.2063 & 3.0241 & 3.1833 & 38 \\
& $\mathrm{~N}$ & 38 & 38 & 38 & 38 & 38 \\
\hline
\end{tabular}




\begin{tabular}{|c|c|c|c|c|c|c|}
\hline & $\begin{array}{l}\text { Std. } \\
\text { Deviation }\end{array}$ & .64019 & .45852 & .49733 & .63741 & .58928 \\
\hline \multirow[t]{3}{*}{ KATU } & Mean & 3.4946 & 3.1784 & 3.2957 & 3.3011 & 3.3514 \\
\hline & $\mathrm{N}$ & 31 & 31 & 31 & 31 & 31 \\
\hline & $\begin{array}{l}\text { Std. } \\
\text { Deviation }\end{array}$ & .60932 & .41092 & .52785 & .53191 & .55661 \\
\hline \multirow[t]{3}{*}{ Karabük Uni. } & Mean & 3.5761 & 3.3988 & 3.6123 & 3.3971 & 3.6203 \\
\hline & $\mathrm{N}$ & 46 & 46 & 46 & 46 & 46 \\
\hline & $\begin{array}{l}\text { Std. } \\
\text { Deviation }\end{array}$ & .77992 & .56683 & 1.38802 & .78059 & .74231 \\
\hline Hacı Bektaş & Mean & 3.4483 & 3.2253 & 3.1552 & 3.2471 & 3.4966 \\
\hline \multirow[t]{2}{*}{ Uni. } & $\mathrm{N}$ & 29 & 29 & 29 & 29 & 29 \\
\hline & $\begin{array}{l}\text { Std. } \\
\text { Deviation }\end{array}$ & .68008 & .70620 & .61388 & .79580 & .82915 \\
\hline \multirow[t]{3}{*}{ Total } & Mean & 3.4810 & 3.2533 & 3.2820 & 3.2862 & 3.4873 \\
\hline & $\mathrm{N}$ & 172 & 172 & 172 & 172 & 172 \\
\hline & $\begin{array}{l}\text { Std. } \\
\text { Deviation }\end{array}$ & .67494 & .54671 & .88092 & .69341 & 69129 \\
\hline
\end{tabular}

Findings according to the institutions demonstrated in Table 6 reveal the highest means as $3.45(69 \%)$ for Cumhuriyet University, 3.71 (74\%) for Atatürk University, 3.39 (68\%) for Erciyes University, 3.49 (70\%) for Karadeniz Technical University, 3.62 (72\%) for Karabük University, and 3.49 (70\%) for Hac1 Bektaş Veli University. According to the highest means, Bennett's model is received appreciation by the lecturers working at Cumhuriyet University, Atatürk University, Karabük University, and Hac1 Bektaş Veli University most, while lecturers working at Erciyes University and Karadeniz Technical University perceive using home and target culture in the EFL classroom as a more important factor in raising intercultural awareness.

Table 7. Means of the factors for groups of education

\begin{tabular}{lllllll}
\hline Education & & $\begin{array}{l}\text { Home and } \\
\text { Target } \\
\text { Culture in } \\
\text { EFL } \\
\text { Classrooms }\end{array}$ & $\begin{array}{l}\text { Classroom } \\
\text { Tasks and } \\
\text { Activities }\end{array}$ & $\begin{array}{l}\text { Vygotskian } \\
\text { Theory of } \\
\text { Interaction }\end{array}$ & $\begin{array}{l}\text { Byram's ICC } \\
\text { Model }\end{array}$ & $\begin{array}{l}\text { Bennett's } \\
\text { Model of } \\
\text { Intercultural } \\
\text { Sensitivity }\end{array}$ \\
& & & & & \\
\hline B.A & Mean & 3.4517 & 3.2601 & 3.2683 & 3.2758 & $\mathbf{3 . 4 7 4 9}$ \\
& $\mathrm{N}$ & 109 & 109 & 109 & 109 & 109 \\
& Std. Deviation & .70372 & .53292 & 1.02159 & .73419 & .72116 \\
\hline M.A & Mean & $\mathbf{3 . 5 0 3 3}$ & 3.2107 & 3.2794 & 3.2497 & 3.4925 \\
& $\mathrm{~N}$ & 51 & 51 & 51 & 51 & 51 \\
& Std. Deviation & .57008 & .56048 & .56490 & .55942 & .62563 \\
\hline PhD & Mean & $\mathbf{3 . 7 3 3 3}$ & 3.4362 & 3.5000 & 3.6600 & 3.7054 \\
& $\mathrm{~N}$ & 10 & 10 & 10 & 10 & 10 \\
& Std. Deviation & .82850 & .68429 & .61237 & .83397 & .68700 \\
\hline Total & Mean & 3.4837 & 3.2556 & 3.2853 & 3.2906 & 3.4937 \\
& $\mathrm{~N}$ & 170 & 170 & 170 & 170 & 170 \\
& Std. Deviation & .67353 & .54947 & .88558 & .69485 & .69005 \\
\hline
\end{tabular}

The highest means of the factors in terms of the educational background of the lecturers are 3.47 (69\%) for B.A, 3.50 (70\%) for M.A, and $3.73(75 \%)$ for PhD. Table 7 shows the fact that among the participants the mean of awareness of using home and the target culture in the EFL classroom is getting higher according to the educational degree of the participants. 
Table 8. Means of the factors for lecturers' believing to be prepared to handle issues of intercultural awareness

\begin{tabular}{|c|c|c|c|c|c|c|c|}
\hline \multicolumn{3}{|c|}{$\begin{array}{l}\text { INTERCULTURAL } \\
\text { AWARENESS }\end{array}$} & $\begin{array}{l}\text { Home and } \\
\text { Target } \\
\text { Culture in } \\
\text { EFL } \\
\text { Classrooms }\end{array}$ & $\begin{array}{l}\text { Classroom } \\
\text { Tasks and } \\
\text { Activities }\end{array}$ & $\begin{array}{l}\text { Vygotskian } \\
\text { Theory of } \\
\text { Interaction }\end{array}$ & $\begin{array}{l}\text { Byram's } \\
\text { ICC Model }\end{array}$ & $\begin{array}{l}\text { Bennett's } \\
\text { Model of } \\
\text { Intercultural } \\
\text { Sensitivity }\end{array}$ \\
\hline \multirow[t]{3}{*}{ Yes } & & Mean & 3.6952 & 3.3672 & 3.3641 & 3.4790 & 3.6512 \\
\hline & & $\mathrm{N}$ & 84 & 84 & 84 & 84 & 84 \\
\hline & & Std. Deviation & ,68335 & .51442 & .61221 & .69212 & .69723 \\
\hline \multirow[t]{3}{*}{ No } & & Mean & 3.3301 & 2.9800 & 3.1765 & 3.1569 & 3.3854 \\
\hline & & $\mathrm{N}$ & 51 & 51 & 51 & 51 & 51 \\
\hline & & Std. Deviation & .62137 & .51497 & .59011 & .63085 & .68597 \\
\hline \multirow{3}{*}{$\begin{array}{l}\text { Have } \\
\text { idea }\end{array}$} & no & Mean & 3.1814 & 3.3910 & 3.2475 & 3.0147 & 3.2669 \\
\hline & & $\mathrm{N}$ & 34 & 34 & 34 & 34 & 34 \\
\hline & & Std. Deviation & .57350 & .55875 & 1.58400 & .69593 & .62486 \\
\hline \multirow{3}{*}{\multicolumn{2}{|c|}{ Total }} & Mean & 3.4817 & 3.2552 & 3.2840 & 3.2884 & 3.4937 \\
\hline & & $\mathrm{N}$ & 169 & 169 & 169 & 169 & 169 \\
\hline & & Std. Deviation & .67694 & .55134 & .88806 & .69915 & .69519 \\
\hline
\end{tabular}

Table 8 shows the lecturers who believe that their educational background has prepared them for intercultural awareness are more aware of the significance of both home and target culture in the EFL classroom, and awareness of lecturers who think that their educational background has no effect on raising intercultural awareness is higher for Bennett's model of intercultural sensitivity. On the other hand, the lecturers who have no idea about the item show interestingly a higher awareness in the classroom tasks and activities.

\subsection{Qualitative results}

It is such a positivistic paradigm that all the informants recognize the strict link between culture and language. In a common sense, they accept that culture and language are interwoven and inseparable. SP4 suggests that it is almost impossible to teach a foreign language without referring to its culture as every language holds some sayings difficult to translate but they can only be explained by culture. $\mathrm{He}$ (SP4) exemplifies it through his experience in the classroom stating:

'Today, in my class, we were talking about marriage. And students were talking about 'escaping with husband'. And they asked me its meaning in English. I told them that there was not such a concept in European countries. Also, they (students) asked me about 'başlık parası' in English. Again, I told them that there was not that concept as well.'

SP4 explains the relation between culture and language by giving examples from sociolinguistic perspectives, which is very similar with Byram's (1989) argument on the need for interdisciplinary approach in FL teaching. By combining cultural studies and media studies, teachers provide students with sociolinguistic perspectives through which they can observe social uses of the target language (Byram, 1989). SP2 emphasizes how the geography even the climate affects the language we use. SP2 states as following:

'The area we live in influences the culture. For example, in Russia people living in cold climate use vocabulary which involves many words related to the cold climate. I studied metaphorical awareness in my master thesis, and the research revealed that metaphorical uses in a language were derived from the cultural issues.' 
In line with SP2, the other participant, SP3, says that 'I think proverbs are the most important evidence of the influence of culture on language.' He (SP3) states that he is learning Russian and compares the cultures, and recognizes the fact that geography has a significant role in shaping our language. However, SP5 offers a perspective that is different from those just noted above as he states:

'We see that in our Prep. School, the foreign teachers from other nations whose culture has similarities with our culture (Turkish culture) learn Turkish language more easily than the other foreign teachers such as fullbrighters from America. I think the problem in terms of teaching EFL in our country results from the fact that we cannot link language with culture.'

The informant (SP5) having a 13-year teaching experience pinpoints the obstacle in teaching EFL in Turkey as EFL teachers' remaining incapable of relating language with culture. A related point worth raising here is that all the informants agree upon the significant link between language and culture, but in practice how often they give place to cultural elements and to cultural insights and perspectives arises some problematic issues.

Analysing the data gathered by the interview the researcher confines the tree main problems that block integrating language and culture in EFL teaching and learning. First, according to the participants, the problems result from students' restricted knowledge about the culture, which leads prejudices and underestimation. By the same token, the second problematic concept is associated with different religious beliefs. And the other problem that lecturers encounter is the priorities in teaching language as the limited time of a course hour mainly involves teaching linguistic skills.

SP4 who has a teaching experience in Germany believes that the important point is that lecturers should explain something different to the students well enough so that it makes sense to them. He (SP4) argues limited knowledge may lead to misunderstandings and it is teachers' duty to explain it in detail by saying in his own words:

'When I was teaching about Turkish culture to the German students, I was trying to explain the Sacrifice Feast, because that was something strange. I explained them that it was not just about killing an animal, rather it was about sharing.'

Students' received knowledge about the target culture prevents them to gain a deeper insight towards 'the other', and sometimes leads the students to exoticize 'the different' as SP5 puts it 'Students sometimes may be a bit chauvinist or I can say that they approach the topic from the nationalist point of view.' SP5 continues by stating that 'There are some students who reject learning about the foreign culture. They feel as if we imposed them the foreign culture and they became culturally assimilated.' Krajka, Marczak, Tatar, and Yildiz (2013) by stressing the need for shifting teachers' roles from that of a transmitter of knowledge to that of partner in a learning process argue for the importance of developing teachers' skills of "text/media interpretation", "interpretation of behavior and ways of avoiding conflict", and "critical cultural awareness" (p. 3). These skills help teachers prepare students to become sensitive towards otherness (Krajka, Marczak, Tatar \& Y1ldı, 2013).

Teachers' role in teaching culture as discussed previously is to seek multiple sources for information and enrich the classroom with different types of teaching approaches and materials as Cortazzi (1990, pp. 63-64) puts it "The aim here would be to provide learners with the conditions to create multiple understandings of one situation and to reflect on varying cultural perspectives, expectations and assumptions, thus raising their awareness, knowledge, and skill". In practical terms, this means that technology-mediated tools and new media such as blogs, web-channels, magazines, and social networks provide teachers with rich materials to familiarize students with the other cultures. Teachers as facilitators should develop practices to show that there might be a wide range of possibilities and the diversity is something beneficial portraying different perspectives. 
SP2 argues that the main problem arises from different religious beliefs stating, 'For instance, when you are trying to present meals, students tend to be prejudiced because of eating pork.' SP2 believes that the best way to eliminate prejudices is 'to have a living experience abroad. For a while, language learners should live in a foreign country whose language they are learning'. The concept of culture is such "a complex, elusive, multi-layered notion" (Furstenberg, 2010, p. 329) that it is rather difficult to understand without direct experience (Kearney, 2010) as Harsch and Poehner (2016, p. 471) consider "student mobility" as "a primary driver for developing second language abilities and interculturality." Accordingly, Holliday (2016, p. 329) suggests "we have the potential through cultural travel to cross boundaries and find ourselves in new domains and at the same time engage positively, creatively and critically with the realities and the people that we find". Bearing in mind that no matter how religions are shaping the cultures, the point is that to embrace different beliefs and develop empathy towards the people who are from different religious origin, the lecturers should reassure that a deeper understanding of culture give students multiple opportunities to receive the world in a globalized perspective.

From the quotations of lecturers above, we can assume that according to Bennet's model, students are close to ethnocentric views as they defensively reject the differences perceiving them from their own cultural reality. From a similar point Osterloh (1990, p. 81) states that "the students' cultural background prompts him to perceive a difference of opinion as an attack on both himself and the group of which he is a part". Olson and Kroeger (2001, p. 120) point the idea as indicating "Individuals and groups notice specific differences and create specific defenses against these differences. These differences feel threatening to their sense of reality".

Another problem is that all the participants interviewed complain of the limited time that restricts the course in 50 minutes depriving the teachers of integrating cultural elements into the class. As this being the case, lecturers prefer neglecting teaching culture by giving priority to teach grammar or following the textbooks which rarely involve cultural elements or bear only European cultures rather than featuring diversity. SP3 states that 'It is certain that there are many problems in teaching culture because we have very limited time and we have to follow the textbook. Hence we initially teach grammar.'

The data obtained by the interview highlights current problems in using multiple teaching materials. Lecturers have very restricted teaching materials including only the textbook. And far more importantly, according to lecturers the textbooks mostly include American or European cultures neglecting other cultures. SP1 indicates 'we have a textbook and we have to work with it in a certain period. It is not easy to be flexible in terms of teaching materials.' Also, she analyzes students' profiles by stating 'These are very suggestive activities, but our teaching methods are unfortunately teacher-centred, and students are accustomed to listening to the teachers and doing activities offered in the textbook.' In line with SP1, SP2 puts 'I, myself, have to prepare materials and do extra work if I have intentions to enable students to make comparison between both cultures.' Also, SP3 states:

I think in textbooks we cannot find such opportunities to develop intercultural awareness,

because they are published by designers who have little knowledge about other cultures.

Publishers or book designers give place to the target culture; I mean British or American culture.'

Statements of lecturers above are very similar to Alptekin's (1993) arguments about textbook authors' preferences. According to Alptekin (1993, p. 137) it is easy and practical to write about their own culture for textbook writers "who normally reside in their own Anglo-American culture, find it hard to compose data that go beyond their "fit"."

SP6 asserts that in discussion parts it is sometimes available to find that kind of topics, however they generally leave these parts untouched as he says 'Actually, there are some discussion parts, but we skip these parts as our students cannot talk fluently in the target language.' He continuously states, 
'Sometimes we encounter dialogues between people from our culture such as "Ahmet and his mother", and in asking directions or address we can see "cami"; so, not often, but there are some elements from our culture in textbooks.' On the other hand, SP12 mentions about the "us-otherness" reciprocity asserting that textbooks do not cover other cultures different from Europe and America. In his words SP12 suggests:

'For me, textbooks do not encourage learners to compare cultures, rather they are controversial and they otherize the cultures apart from Western and European cultures, because they give almost no place to other cultures. For instance, in writing sections there are some discussion topics which are not commonly discussed in an open way in our culture among the youngsters.'

The point is that lecturers criticize publishers by designing the textbooks from a narrow point of view. It is also pointed by Dunnett, Dubin and Lezberg (1990, p. 153) that "it is more often the case that typical English language instructional materials communicate cultural messages from a one-dimensional view". Multiple teaching materials such as web blogs, magazines, and videos can help to solve the problem of one-sided viewpoint of textbooks. The problem lies in the fact that lecturers use only textbooks as teaching material, which is the case for most of the EFL classes "which in practice devote the major portion of their instructional time to the four basic language skills" (Dunnett, Dublin \& Lezberg, 1990, p. 157).

As one of the participants pinpoints above, students' language competence and speaking skills are insufficient to discuss a topic in the target language. However, listening and writing practices for those students who are not skilled in speaking fluently can be preferable. As it is discussed in literature review, teachers should design tasks for intercultural awareness in accordance with considering students' linguistic skills, age, interest, motivation, and etc. Internet provides a variety of sources that can be received by little research. By the way, when students are motivated, they will be eager to participate in activities and use the target language. According to Rubenfeld, Sinclair and Clément (2007, p. 309) students' motivations "for learning a second language influences adaptation in the foreign culture". Also, Culhane (2004, p. 59) asserts that students' motivation for interaction is related to students' "focus on integrating into the cultural context of L2". Using new media as suggested in the current literature raises the interaction and the interest among the students, and naturally the more they use the target language the more likely that they get developed in linguistic skills.

Interview results show us that lecturers mostly believe that qualitative methods better suit assessing students' intercultural awareness. On the other hand, it is observed by the researcher that lecturers have very little knowledge about the assessment of intercultural education as they have no experience of teaching intercultural awareness, which shows us the necessity of teacher training programmes. By intercultural training the researcher refers to obtaining ability in "how to focus on cultural threads and put aside cultural block - how to ask questions, to talk to people, to recognize threads in one's personal cultural trajectory, to connect this to the threads of others to find threads that one can relate to" (Holliday, 2016, p. 329). In this study the researcher tries to present multiple ways of assessing intercultural education to help teachers integrate cultural issues into EFL teaching.

According to SP1, questionnaires are not effective in measuring anything as the results are not reliable, because students do not like filling in questionnaires. Rather, she reasonably suggests interviews stating with her own words:

I would not prefer quantitative methods such as questionnaires, because it is widely accepted fact that participants fill in the surveys without reading the items. Focus-grouping interviews may be an effective assessment method.' 
From the same perspective, SP5 thinks that writing papers can be efficiently used to understand students' development as she offers 'we can ask students to write about a situation and make comparisons. Additionally, she (SP5) suggests 'Students like recording video, so they can prepare sketches like role-plays, and I think it should be productive rather than testing'. Similarly, SP3 recommends teacher-guided interviews as he says, 'I do not recommend quantitative methods such as testing or written exams, but interviews can be the best way of assessment'.

Pointing from a rather different perspective SP2 believes that qualitative methods cannot be used as students' linguistic level is not enough for such methods. He (SP2) asserts 'Students have difficulty in speaking English, so maybe testing or multiple-choice can be used as an assessment method'. It can be true for the early stages; however as suggested by other interviewees there are many other ways rather than interviews like written methods and role-plays. By the same token, when it comes to the issue of assessment, SP6 and SP4 regard it only through quantitative perspectives neglecting qualitative ways of assessment. SP6 points that 'I do not think that it is something that should be assessed'. Here, the participant argues for the developmental process of intercultural awareness and stresses the necessity of developing students' intercultural sensitivity as he continues his words with stating 'to be honest, we should provide students with different thoughts, beliefs, and cultures, because they are not very open to other cultures'. Similarly, SP4 indicates 'I do not know how to assess intercultural awareness, because it is not something that you can test'. Both SP6 and SP4 relate the assessment with quantitative methods and hence, they do not have clear idea about assessing intercultural awareness.

\section{Discussion}

Quantitative data shows us that the lecturers' awareness is greater in the 23-30 age group for all the factors except for the factor of Vygotsky's interactional theory. The lowest mean of lecturers' awareness for all the factors is in the 51+ age group. Hence, we can state according to the results that younger lecturers have higher degree of awareness compared to older lecturers.

In a similar vein, according to the findings, the lecturers' awareness is getting higher while the years of teaching experience decrease for the same factors. Except for the factor of Vygotskian theory, the level of awareness is the highest in the group with 0-1 year of experience. We can infer that lecturers with more working experience are not aware of the intercultural education as much as lecturers with less working experience.

Considering the gender of the participants, we can obtain from the data that the awareness of female participants is greater in four factors, except for the factor of Vygotsky's interactional theory. The awareness of the male lecturers is greater only in the factor of Vygotskian theory of interaction. Hence, it is worth noting that female lecturers are more aware of the factors in terms of intercultural teaching and learning.

From the findings, we can conclude that although lecturers are aware of the importance of integrating both home and target culture into the classes, developing interaction among the learners, developing intercultural communicative competence and intercultural sensitivity, they are not sure about how to put intercultural learning into practice for EFL classroom tasks and activities. This conclusion is compatible with the study by Atay, et al (2009), which asserts the necessity of teacher training programmes including intercultural courses to help teachers with practices on intercultural communication. Also, Sercu (2005, p. 131) finds out the similar results in his large-scale study that reveals FL teachers' willingness to "interculturalise foreign language education". However, the same study points the reasons that prevent the integration of intercultural education as likely to be "a certain feeling of uneasiness about the fact that intercultural competence teaching might entail a reduction of the teaching 
time that can be devoted to improving learners' language skills" (Sercu, 2005, p. 138). It is inferred from the findings that academic degree prepares the lecturers to handle intercultural issues. However, the problem arises on the integration of the intercultural education into the language learning as Yeşil and Demiröz (2017) point in their study.

According to the interview, students' existing stereotypes towards the target culture block the integration of cultural elements into EFL classrooms. Hence, lecturers prefer ignoring discussion of cultural elements. In a similar vein, Sercu (2005, p. 137) indicates in his study that some FL teachers are hesitant about integrating intercultural teaching as they believe "intercultural competence teaching reinforces pupils' already existing stereotypes."

Lecturers' responses point up the fact that teaching materials for EFL education are limited to the textbook which places pretty much emphasis on western cultures. By the same token, Karabinar and Guler (2013, p. 1326) found out in their study that the main focus of the textbooks is on the British or American cultures, and "the lack of information about various cultures" has the potential to "pose a risk of stereotyping." Accordingly, much instructional time of a course has been devoted to teaching linguistic skills, and it is generally teacher-fronted. As students are not familiar with other cultures and the textbook dominantly involves western cultures, lecturers find it time consuming to explain cultural differences for students who are unmotivated for most of the time. Also, Atay, et al. (2009, p. 1615) indicate in their study that teaching target culture is restricted to help "the students understand their own culture better, rather than getting to know the target or foreign culture better" due to the instructional time constraints. From the same token, Tolosa, Biebricher, East and Howard (2018) find out in their study that although teachers treat the interculturality as an important goal to achieve in the FL education, "it was not consistently put into practice, mainly due to the fact that intercultural learning aims were not the foci of the teachers' lessons" (p.228). This finding is also compatible with Byram's reflective study in which the author finds out that "there is still a lack of understanding among teachers with respect to the significance of intercultural competence and its relation to linguistic competence" (Byram, 2014, p. 209).

Teachers need guidance and training to practice confidently intercultural competence teaching in the classroom, especially in terms of assessment methods as the findings suggest that lecturers do not have a clear idea about the assessment and evaluation methods to apply with intercultural competence. This finding reminds of Byram's comments on the evaluation of the intercultural process over the years as stating that "the question of assessment remains insufficiently developed" (Byram, 2014, p. 209), which demands considerable number of researches for the assessment of intercultural awareness.

\section{Conclusions}

As the qualitative data shows, EFL students at university level in Turkey are prejudiced towards the target culture. Students have little chance to interact with a presenter of the target culture. According to the findings of the study, students, in Turkey, get the information about the target culture through the ELF teacher and the textbook. However, lecturers believe that textbooks are not multicultural, rather western cultures are dominating the textbooks. According to the lecturers involved in this study, students are not motivated to learn about other cultures because of their stereotypical assumptions.

Whereas the quantitative data shows us that lecturers are aware of the importance of integrating culture and language in order to raise students' intercultural awareness, the qualitative data presents the problems encountered while integrating culture into the language teaching. Considering the current situation in the EFL classroom in Turkey we can conclude that interaction happens very rarely between learners and foreigners as lecturers believe that students' linguistic skills are inadequate for such 
interaction. Moreover, students are in ethnocentric stages as they are defensive of their culture towards the target culture and it is challenging to discuss about the target culture. And lastly, EFL lecturers mostly focus their teaching intentions on the linguistic knowledge rather than language use, hence they neglect the intercultural communicative competence for most of the time.

As the textbooks are insufficient to teach about diverse cultures and develop intercultural competence, policy makers and curriculum designers should corporate with EFL teachers on the teaching materials. EFL learning is not only a matter of learning linguistic skills, rather, students should use the language appropriately in social settings both for written texts and spoken contexts.

\section{References}

Agudelo, J. J. (2007). An intercultural approach for language teaching: Developing critical cultural awareness. Ikala, 12(18), 185-217.

Aguilar, M. J. (2007). Dealing with intercultural communicative competence in the foreign language classroom. In E. A. Soler \& M. P. Jorda (Eds.), Intercultural language use and language learning (pp. 59-78). Dordrecht: Springer.

Almalki, S. (2016). Integrating quantitative and qualitative data in mixed methods research challenges and benefits. Journal of Education and Learning, 5(3), 288-296. DOI: 10.5539/jel.v5n3p288.

Alptekin, C. (1993). Target-language culture in EFL materials. ELT Journal, 47(2), 136-143.

Arasaratnam, L. A., \& Doerfel, M. L. (2005). Intercultural communication competence: Identifying key components from multicultural perspectives. International Journal of Intercultural Relations, 29, 137-163.

Atay, D., Çamlıbel, Z., Ersin, P., Kaşlıoğlu, Ö., \& Kurt, G. (2009). Turkish EFL teachers' opinions on intercultural approach in foreign language education. Procedia Social and Behavioral Sciences I, $1,1611-1616$.

Bennett, M. J. (1993). Towards ethnorelativism: A developmental model of intercultural sensitivity. In R. M. Paige (Ed.), Education for the intercultural experience (pp. 21-71). Yarmouth: Intercultural Press.

Bennett, M. J. (2004). Becoming interculturally competent. In J. S. Wurzel (Ed.), Toward multiculturalism: A reader in multicultural education (2nd ed., pp. 62-77). Newton: Intercultural Resource Corporation.

Bennett, M. J. (2009). Defining, measuring, and facilitating intercultural learning: A conceptual introduction to the intercultural education double supplement. Intercultural Education, 20(1), 1-13. DOI: $10.1080 / 14675980903370763$.

Bush, M. D. (2007). Facilitating the integration of culture and vocabulary learning: The categorization and use of pictures in the classroom. Foreign Language Annals, 40(4), 727-745.

Byram, M. (1989). Cultural studies in foreign language education. Philadelphia: Multilingual Matters.

Byram, M. (1990). Foreign language teaching and young people's perceptions of other cultures. In B. Harrison (Ed.), Culture and the language classroom (pp. 76-87). Hong Kong: Modern English Publications and the British Council. 
Byram, M. (Ed.). (1997). Teaching and assessing intercultural communicative competence. Clevedon: Multilingual Matters.

Byram, M. (2014). Twenty-five years on - from cultural studies to intercultural citizenship. Language, Culture and Curriculum, 27(3), 209-225. DOI: 10.1080/07908318.2014.974329.

Byram, M., Nichols, A., \& Stevens (Eds.). (2001). Developing intercultural competence in practice. Clevedon: Multilingual Matters.

Canto, S., Graaff, R. d., \& Jauregi, K. (2014). Collaborative tasks for negotiation of intercultural meaning in virtual worlds and video-web communication. In M. Gonzalez-Lloret, \& L. Ortega (Eds.), Technology-mediated TBLT: Researching technology and tasks (pp. 183-212). Philadelphia: John Benjamins Publishing.

Chastain, K. (1976). Developing second language skills: Theory to practice (2nd ed.). Chicago: Rand McNally College.

Clouet, R. (2006). Between one's own culture and the target culture: The language teacher as intercultural mediator. Porta Linguarum, 5, 53-62.

Corbett, J. (2003). An intercultural approach to English language teaching. (M. Byram, \& A. Phipps, Eds.) New York: Multilingual Matters.

Cortazzi, M. (1990). Cultural and educational expectations in the language classroom. In B. Harrison (Ed.), Culture and the language classroom (pp. 54-65). Hong Kong: Modern English Publications and the British Council.

Creswell, J. W. (2012). Educational research: Planning, conducting, and evaluating quantitative and qualitative research. Boston: Pearson Education.

Creswell, J. W. (2014). Research design: Qualitative, quantitative, and mixed methods approaches (4th ed.). Thousand Oaks: Sage Publications.

Culhane, S. F. (2004). An intercultural interaction model: Acculturation attitudes in second language acquisition. Electronic Journal of Foreign Teaching, 1(1), 50-61.

Duff, S., \& Mayes, J. (2001). Family life and regional identity - comparative studies while learning French. In M. Byram, A. Nicholas, \& D. Stevens (Eds.), Developing intercultural competence in practice (pp. 93-110). Exeter: Multilingual Matters.

Dunnett, S. C., Dubin, F., \& Lezberg, A. (1990). English language teaching from an intercultural perspective. In J. M. Valdes (Ed.), Culture bound: Bridging the cultural gap in language teaching (4th ed., pp. 148-161). Cambridge: Cambridge University Press.

Ferguson-Patrick, K., \& Jolliffe, W. (2018). Cooperative learning for intercultural classrooms: Case studies for inclusive pedagogy. New York: Routledge.

Furstenberg, G. (2010). Making culture the core of the language class: Can it be done? The Modern Language Journal, 94(2), 329-332.

Galante, A. (2014). Developing EAL learners' intercultural sensitivity through a digital literacy project. TESL Canada Journal, 32(1), 53-66.

Ganem-Gutiérrez, G. A. (2014). The third dimension: A sociocultural theory approach to the design and evaluation of 3D virtual worlds tasks. In M. Gonzalez-Lloret, \& L. Ortega (Eds.), Technologymediated TBLT: Researching technology and tasks (pp. 213-238). Philadelphia: John Benjamins Publishing. 
Garrett-Rucks, P. (2014). Measuring instructed language learners' IC developments: Discrepancies between assessment models by Byram and Bennett. International Journal of Intercultural Relations, 41, 181-191.

Georgieva, I. (2001). An approach to implementing a cultural studies syllabus. In M. Byram, A. Nicholas, \& D. Stevens (Eds.), Developing intercultural competence in practice (pp. 77-92). Exeter: Multilingual Matters Ltd.

Gipps, C. (2002). Sociocultural perspectives on assessment. In G. Wells, \& G. Claxton (Eds.), Learning for life in the 21st century: Sociocultural perspectives on the future of education (pp. 7383). Cornwall: Blackwell Publishing.

Gonzalez-Lloret, M., \& Ortega, L. (2014). Towards technology-mediated TBLT: An introduction. In M. Gonzalez-Lloret, \& L. Ortega (Eds.), Technology-mediated TBLT: Researching technology and tasks (pp. 1-22). Philadelphia: John Benjamins Publishing.

$\mathrm{Gu}, \mathrm{X}$. (2016). Assessment of intercultural communicative competence in FL education: A survey on EFL teachers' perception and practice in China. Language and Intercultural Communication, 16(2), 254-273. DOI: 10.1080/14708477.2015.1083575.

Hammer, M. R., Bennett, M. J., \& Wiseman, R. (2003). Measuring intercultural sensitivity: The intercultural development inventory. International Journal of Intercultural Relations, 27(4), 421443.

Harrison, B. (Ed.). (1990). Culture and the language classroom. Hong Kong: Modern English Publications and the British Council.

Harsch, C., \& Poehner, M. E. (2016). Enhancing student experiences abroad: The potential of dynamic assessment to develop student interculturality. Language and Intercultural Communication, 16(3), 470-490. DOI: 10.1080/14708477.2016.1168043.

Hoff, H. E. (2014). A critical discussion of Byram's model of intercultural communicative competence in the light of Bildung theories. Intercultural Education, 25(6), 508-517. DOI: 10.1080/14675986.2014.992112.

Holliday, A. (2016). Difference and awareness in cultural travel: Negotiating blocks and threads. Language and Intercultural Communication, 16(3), 318-331. DOI: 10.1080/14708477.2016.1168046.

Holmes, P., \& O'Neill, G. (2012). Developing and evaluating intercultural competence: Ethnographies of intercultural encounters. International Journal of Intercultural Relations, 36(5), 707-718.

Karabinar, S., \& Guler, C. Y. (2013). A review of intercultural competence from language teachers' perspective. Procedia Social and Behavioral Sciences, 70, 1316-1328. DOI: 10.1016/j.sbspro.2013.01.193.

Kearney, E. (2010). Cultural immersion in the foreign language classroom: Some narrative possibilities. The Modern Language Journal, 94(2), 332-336.

Koester, J., \& Lustig, M. W. (2015). Intercultural communication competence: Theory, measurement, and application. International Journal of Intercultural Relations, 48, 20-21.

Krajka, J., Marczak, M., Tatar, S., \& Y1ldız, S. (2013). Building ESP teacher awareness through intercultural tandems - post-practicum experience. English for Specific Purposes World, 14(38), 118. 
Lee, L. (2012). Engaging study abroad students in intercultural learning through blogging and ethnographic interviews. Foreign Language Annals, 45(1), 7-21. DOI: 10.111/j.19449720.2012.01164.x.

Liddicoat, A. J. (2005). Teaching Languages for Intercultural Communication. Retrieved from https://www.resourcefulindonesian.com/uploads/1/1/2/5/11252883/teaching_languages_fpr_interc ultural_communication.pdf

Lin, W.-C., Shie, J.-S., \& Holmes, P. (2017). Enhancing intercultural communicative competence through online foreign language exchange: Taiwanese students' experiences. Asian Journal of Applied Linguistic, 4(1), 73-88.

Littlewood, W. (2014). Communication-oriented language teaching: Where are we now? Where do we go from here? Language Teaching, 47(3), 349-362. DOI: 10.1017/S0261444812000134.

Liu, J., \& Fang, F. (2017). Perceptions, awareness and perceived effects of home culture on intercultural communication: Perspectives of university students in China. System, 67, 25-37.

Madjarova, T., Botsmanova, M., \& Stamatova, T. (2001). I thought my teacher fancied me. In M. Byram, A. Nicholas, \& D. Stevens (Eds.), Developing intercultural competence in practice (pp. 236-245). Exeter: Multilingual Matters Ltd.

Mahon, J. A., \& Cushner, K. (2014). Revising and updating the inventory of cross-cultural sensitivity. Intercultural Education, 25(6), 484-496. DOI: 10.1080/14675986.2014.990232.

Morgan, C. (2001). The international partnership project. In M. Byram, A. Nicholas, \& D. Stevens (Eds.), Developing intercultural competence in practice (pp. 11-28). Exeter: Multilingual Matters Ltd.

Müller-Hartmann, A., \& Ditfurth, M. S. (2010). Research on the use of technology in task-based language teaching. In M. Thomas, \& H. Reinders (Eds.), Task-based language learning and teaching with technology (pp. 17-40). New York: Continuum International Publishing.

Nieto, S. (2002). Language, culture, and teaching: Critical perspectives for a new century. New Jersey: Lawrence Erlbaum Associates.

Olson, C. L., \& Kroeger, K. R. (2001). Global competency and intercultural sensitivity. Journal of Studies in Intercultural Education, 5(2), 116-137.

Osterloh, K. H. (1990). Intercultural differences and communicative approaches to foreign language teaching in the third world. In J. M. Valdes (Ed.), Culture bound: Bridging the cultural gap in language teaching (4th ed., pp. 77-84). Cambridge: Cambridge University Press.

Parsons, J., \& Junge, P. (2001). Why do Danes put their elderly in nursing homes? - Working outside the classroom with adult second language learners. In M. Byram, A. Nicholas, \& D. Stevens (Eds.), Developing intercultural competence in practice (pp. 203-216). Exeter: Multilingual Matters Ltd.

Perry, L. B., \& Southwell, L. (2011). Developing intercultural understanding and skills: Models and approaches. Intercultural Education, 22(6), 453-466. DOI: 10.1080/14675986.2011.644948.

Porto, M. (2010). Culturally responsive L2 education: An awareness-raising proposal. ELT Journal, 64(1), 45-53.

Rubenfeld, S., Sinclair, L., \& Clément, R. (2007). Second language learning and acculturation: The role of motivation and goal content congruence. Canadian Journal of Applied Linguistics, 10(3), 309-329. 
Sandelowski, M. (2000). Focus on research methods: Combining qualitative and quantitative sampling, data collection, and analysis techniques in mixed-method studies. Research in Nursing and Health, 23(3), 246-255.

Sayer, P., \& Meadows, B. (2012). Teaching culture beyond nationalist boundaries: National identities, stereotyping, and culture in language education. Intercultural Education, 23(3), 265-279. DOI: 10.1080/14675986.2012.702446.

Sellami, A. L. (2000). Teaching towards cultural awareness and intercultural competence: From what through how culture is? Annual meeting of teachers of English to speakers of other languages, (pp. 1-13). Vancouver, Canada.

Sercu, L. (2005). Foreign language teachers and intercultural competence: An international investigation. (M. Byram, \& A. Phipps, Eds.) New York: Multilingual Matters.

Sercu, L. (2006). The foreign language and intercultural competence teacher: The acquisition of a new professional identity. Intercultural Education, 17(1), 55-72. DOI: 10.1080/14675980500502321.

Stromquist, N. P., \& Monkman, K. (2014). Globalization and education: Integration and contestation across cultures. Lanham: Rowman \& Littlefield.

Taguchi, N., Li, S., \& Xiao, F. (2016). Effects of intercultural competence and social contact on speech act production in a Chinese study abroad context. The Modern Language Journal, 100(4), 775-796. DOI: 10.1111/modl.12349.

Tolosa, C., Biebricher, C., East, M., \& Howard, J. (2018). Intercultural language teaching as a catalyst for teacher inquiry. Teaching and Teacher Education, 70, 227-235. DOI: 10.1016/j.tate.2017.11.027.

Wang, J., Lin, E., Spalding, E., Odell, S. J., \& Klecka, C. L. (2011). Understanding teacher education in an era of globalization. Journal of Teacher Education, 62(2), 115-120. DOI: $10.1177 / 0022487110394334$.

Williams, B., Onsman, A., \& Brown, T. (2010). Exploratory factor analysis: A five-step guide for novices. Journal of Emergency Primary Health Care, 8(3), 1-13.

Yeşil, Ş., \& Demiröz, H. (2017). An exploration of English language teachers' perceptions of culture teaching and its effects on students' motivation. International Journal of Progressive Education, 13(1), 79-95.

Yong, A. G., \& Pearce, S. (2013). A beginner's guide to factor analysis: Focusing on exploratory factor analysis. Tutorials in Quantitative Methods for Psychology, 9(2), 79-94. DOI: 10.20982/tqmp.09.2.p079. 


\section{Dil öğretiminde kültürlerarası farkındalığın geliştirilmesi: Türkiye'deki İngilizce öğretim görevlilerinin anlayışları}

\section{$\ddot{O} \mathbf{z}$}

Bu çalışma, İngilizce öğretim görevlilerinin kültürlerarası eğitim ve öğretim materyalleri, sınıf içi etkinlikler, değerlendirme ve öğretmenlerin kültürlerarası farkındalık geliştirmedeki rolünü içeren sınıf uygulamaları hakkındaki görüşlerini ortaya koymayı amaçlamaktadır. Türkiye'deki üniversite düzeyinde EFL sınıflarındaki mevcut durum hakkında bilgi edinmek için, öğretim görevlilerinin görüş ve sınıf uygulamaları bir anket ve mülakat ile incelenmiştir. Hem nicel hem de nitel araştırmayı birleştiren bu çalışma, karma yöntem prosedürüne göre tasarlanmış ve sıralı açıklayıcı stratejiyi izlemiştir. Çalışma, altı devlet üniversitesinin hazırlık okullarından 172 İngilizce öğretim görevlisini kapsamaktadır. Rastgele seçilen 12 öğretim görevlisi gönüllü olarak görüşmeye katılmıştır. Araştırmaya katılan kurumlar; Atatürk Üniversitesi, Cumhuriyet Üniversitesi, Erciyes Üniversitesi, Hacı Bektaş Veli Üniversitesi, Karabük Üniversitesi ve Karadeniz Teknik Üniversitesi'dir. Nicel sonuçlar, öğretim görevlilerinin hem kendi kültürünü hem de hedef kültürü sınıflara entegre etmenin ve öğrencilerin iletişimsel becerilerini, kültürlerarası iletişimsel yetkinliğini ve kültürlerarası duyarlılığını geliştirmenin öneminin farkında olmalarına rağmen, kültürler arası öğrenmenin nasıl uygulanacağı konusunda yeterli bilgiye sahip olmadıklarını göstermektedir. Buna göre, mülakat sonuçları, kültürlerarası farkındalık hakkında öğretimi engelleyen sorunları ortaya koymakta ve öğretim görevlilerinin, özellikle kültürlerarası beceri uygulamada ölçme ve değerlendirme yöntemleri hakkında net bir fikirleri olmadığı için değerlendirme yöntemleri açısından rehberlik ve eğitime ihtiyaçları olduğunu ortaya koymaktadır.

Anahtar sözcükler: EFL öğretim görevlileri; dil öğretimi; hedef kültür; kültürlerarası farkındalık; kültürlerarası duyarlilik

\section{AUTHOR BIODATA}

Belkıs Zeynep Özışık is an assistant professor at Yozgat Bozok University in Faculty of Education.

Savaş Yeşilyurt is an assistant professor at Atatürk University in Tourism Faculty.

Hakan Demiröz is an assistant professor at Sivas Cumhuriyet University in Faculty of Education. 